\title{
Dietary supplements and body management of practicers of physical activity in gyms
}

\author{
Suplementos alimentares e gerenciamentos do corpo de praticantes \\ de atividade física em academias de ginástica
}

Alan Camargo Silva (http://orcid.org/0000-0003-1729-5151) ${ }^{1}$

Sílvia Maria Agatti Lüdorf (http://orcid.org/0000-0002-8752-3431) ${ }^{1}$

${ }^{1}$ Escola de Educação Física e Desportos, Universidade Federal do Rio de Janeiro. Av. Carlos Chagas Filho 540, Cidade Universitária. 21941-599 Rio de Janeiro RJ Brasil.

alan10@zipmail.com.br

\begin{abstract}
The use of dietary supplements integrates one of the strategies physical activity practicers employ to manage their bodies in contemporary times. This research sought to identify and analyze the multiple uses of dietary supplements done by these practicers and what such uses represent for them with regard to managing their own bodies. A qualitative study was conducted based on the application of online questionnaires to 67 physical activity practicers who frequent gyms. There was also an observation of the groups $d y$ namics in the internet. The resulting empirical material was analyzed using content analysis. Results indicated that part of these practicers believe that dietary supplements aid in gaining muscular mass and improve performance. Furthermore, some of them question the effects of such products on the body although they claim that dietary supplements facilitate diets or should be used only when prescribed by health professionals. In conclusion, there are different ways of using these products, which are often evaluated by consumers. Key words Dietary supplements, Fitness centers, Physical education and training, Diet, food, and nutrition, Resistance training
\end{abstract}

Resumo Os usos de suplementos alimentares fazem parte de uma das estratégias em que os praticantes de atividade física gerenciam seus corpos na contemporaneidade. A presente pesquisa buscou identificar e analisar os múltiplos usos dos suplementos alimentares por praticantes de atividade física e o que esses consumos representam para os usuários no que diz respeito a gerenciar o próprio corpo. Empreendeu-se um estudo qualitativo que se baseou nas aplicações de questionários no ambiente da internet a 67 praticantes de atividades físicas de academias de ginástica. Observou-se também a dinâmica dos grupos na internet. O material empírico foi analisado com base na análise de conteúdo. Os resultados indicaram que parte dos praticantes de atividades físicas acredita que os suplementos alimentares potencializam o ganho de massa muscular e aprimoram o desempenho. Já alguns questionam os efeitos de tais produtos no organismo, embora afirmem que facilitam a dieta cotidiana ou devem ser consumidos caso tenham sido prescritos por profissionais de saúde. Conclui-se que existem diferentes maneiras de usar esses produtos, que são frequentemente avaliados pelos consumidores.

Palavras-chave Suplementos alimentares, Academias de ginástica, Educação física e treinamento, Alimentos, dieta e nutrição, Treinamento de resistência 


\section{Introduction}

The notions of body vary depending on the historical period, social contexts and groups that are taken into consideration. The body as a sociocultural construction beyond anatomophysiological conceptions effectively originated from Mauss's ${ }^{1}$ view of body techniques in the early twentieth century. From this conceptual and theoretical foundation, countless reflective and empirical works were developed in the field of Human and Social Sciences in order to understand the body beyond its biological aspects.

Through the application of this analytical lens to the discussions on the concept of body, it is argued that the use of dietary supplements make up a contemporary phenomenon engendered by a somatic culture. This somatic culture encompasses any method of body management aimed at improving health within the framework of biomedical rationality, a phenomenon that is increasingly evident in contemporary times ${ }^{2}$.

Although the concern with the ingestion of substances has varied throughout different societies since Antiquity, the use of dietary supplements, also called food, nutritional or sports supplements, is part of a current reality in which subjects increasingly manage their bodies as if these existed separately from their own selves. This is intensified by those practicers of physical activities in gyms who monitor or manage their athletic performance, physical appearance or health ${ }^{3}$.

Considering that the modifications of the body have become a reality according to the sociocultural context ${ }^{4}$, this study questions how dietary supplements fit into the body management routines of physical activity practicers. If the subject becomes a producer of his identity through body changes, the combination of exercises and such products points towards a " $[. .$. management of one's own the body as if it were a machine one must be optimized to yield its best results"s.

The literature on the use of dietary supplements by physical activity practicers in the context of gyms was mainly quantitative. Some studies investigate the effects or physiological efficiency of these products ${ }^{6-8}$. Others are concerned with the prevalence and motivations behind the use of the most and the least consumed substances, sometimes correlating them to users' profiles $^{9-15}$. Some works also analyze which nutrition information and professionals or sources users consult before taking products ${ }^{1-21}$. Addition- ally, there are also studies on the impacts of the indiscriminate use of dietary supplements, either by overuse or the lack of professional supervision, which may lead to health problems such as chemical dependency or kidney, liver and/or heart disease and injuries ${ }^{22-24}$.

However, qualitative studies that go deeper into the symbolic uses or social logics concerning the use of dietary supplements are still incipient. Only Atkinson's ${ }^{25}$ work identified how the marketing and use of these products are based primarily on ideals of masculinity, in addition to the study by Sabino et al. ${ }^{26}$, which addressed the meanings attributed to nutritional supplementation and dietary habits by a group of inveterate frequenters of fitness centers.

Hence, the objective of this research was to identify and analyze the multiple uses of dietary supplements by physical activity practicers, and what these uses represent for them with regard to managing their own bodies.

\section{Methods}

This study uses a qualitative approach, as it sought to identify the meanings attributed by the respondents to a given social phenomenon or reality ${ }^{27}$.

The following criteria were employed in the selection of the participants, in order to broaden the spectrum of personal perspectives researched: a) the participant must be aged eighteen years old or more; b) be a current member or have joined a gym at some point in life; c) have bought or used at least one type of dietary supplement, with or without a dietitian's prescription; d) have practiced or be a practicer of weight training.

Questionnaires were applied due to their large contingent of answers and because they allow the participants to feel more comfortable expressing what they think, feel or act in relation to the research topic. The questions were of the "open" type in order to stimulate free responses. The instrument contained three sections of questions: the first mapped the sociodemographic profile of the participants and their relations with physical exercise; the second sought to comprehend how they used the products; and the third aimed at understanding their conceptions about dietary supplements.

Considering evidence that researching the use of dietary supplements interferes in the face-toface relationship between researcher-participant, thus becoming a "delicate" study question ${ }^{28}$, the 
questionnaire was answered online ${ }^{29}$. Using the possibilities of the internet while respecting ethical rigor is a current and quickly growing procedure in scientific publications, and may facilitate the collection of data for some studies ${ }^{30}$.

The questionnaire link was posted on social networks between May and August 2016, especially on all 120 Brazilian Facebook groups dedicated to discussing physical activity, nutrition and dietary supplements. Facebook was emphasized since it was considered the largest virtual space for connecting people in the world ${ }^{31}$. During this period of immersion in Facebook, it was possible to follow and learn about the dynamics of this research locus. Thus, the message exchanges or behaviors adopted by the members of each community, the discussion forums created and the images or photos shared within the groups were fundamental for the contextualization, interpretation and analysis of the questionnaires.

In this context, of the 174 subjects who answered the questionnaire, 67 were selected, 38 men and 29 women, because they met the criteria and answered all the questions. Most subjects were between 18 and 40 years old, earning an average monthly income equal to between 2 and 20 times the minimum wage, which amounts to $\mathrm{R} \$ 1,450.00$ to $\mathrm{R} \$ 14,499.99$, approximately USD 356.52 to USD 3,565.19.

The data analysis conducted here was based on Silverman's ${ }^{27}$ discussion of the importance of organizing and classifying findings in qualitative studies. This study was oriented based on the method of classic content analysis described by Bauer ${ }^{32}$, more precisely the procedure that extracts categories from inferences of textual materials and transfers them to their social context.

This study was approved in the Research Ethical Committee of the University Hospital Clementino Fraga Filho of the Federal University of Rio de Janeiro.

\section{Results}

The categories extracted in the analysis led to the construction of two thematic axes. In the first, the various uses of dietary supplements by physical activity practicers will be highlighted. In the second axis, the representations of users of these products regarding the routine of managing their bodies will be problematized.

\section{The plurality and the (in)efficacy of the act of ingesting dietary supplements}

For most of the physical activity practicers who answered the questionnaire, the use of dietary supplements meant a physical or aesthetic change. The symbolic charge represented by muscle mass gains in association with dietary supplement intake seemed to be one of the main aspects practicers perceived:

I feel a change in my physical development. (Male, 36 years old, teacher).

I have been using them only recently, yet I achieved a gain of lean mass. (Female, 28 years old, university student).

I've gained muscle mass. (Male, 33 years old, teacher).

This reality seems to reinforce a common feature among practicers who frequent weight training spaces, which is that their main objective in these places is to change their physical aspects, or as better put by Hutson's ${ }^{33}$ perspective, to legitimize a kind of body authority in the fitness field that is morally constructed at all times.

Using one of Le Breton's ${ }^{5}$ ideas, it can be stated that the combination of being a physical activity practicer with consuming dietary supplements is grounded on the notion of "incompleteness of the body". For Le Breton ${ }^{34}$, the body continually becomes an alter ego to be domesticated and modified in the face of contemporary patterns of beauty, health and performance. This reality exists because the body often becomes a kind of "business card" one must have in order to be accepted or to belong socially ${ }^{4}$.

It is noteworthy that the profile/cover photos of the Facebook groups on which the questionnaire was posted generally referred to very bulky bodies in terms of muscle in order to attract users who crave these more hypertrophied body models. Group managers opted for images that put muscle in the foreground, such as those of superheroes or photos international bodybuilding athletes.

Thus, the need to use dietary supplements in order to manage muscle mass quantity or shape represents what Helman ${ }^{35}$ states: the body ends up becoming a collection of parts and pieces to be manipulated by the subject. These representations of the visual aspect related to the fragmentation, specialization and valuing of the body derive from the advent of anatomoclinical procedures that legitimize part of biomedical rationality ${ }^{36}$. 
Other reports indicate a search for the satisfaction of certain body longings linked to the notion of performance. In other words, for the subjects, the use of dietary supplements not only resulted in more muscle, but also aided physical performance or increased fitness during their exercises:

I have more stamina during my activities. (Female, 30 years old, teacher).

I feel as if I were fueling my muscles. (Male, 31 years old, executive).

Practicers argued that after ingesting these products they felt more invigorated, both in terms of gaining body results and improving performance during exercises. With regard to this relation, Neville et al. ${ }^{37}$ stress how the search for performance may be marked not only by the use of physical practices, but also by the experience of identity demarcation through the improvement of physical fitness.

The use of dietary supplements therefore brings closer the identities of amateur physical activity practicers and of high-performance athletes involved in sports. Apropos, Le Breton ${ }^{5}$ points out that sports create a "new body fashion" by instituting care modes or ways of conceiving these, in addition to the gym itself, a place that welcomes the overvalued body. It is in this context that the professional institutionalization of sports by means of the so-called "sports" supplements affects the body management of amateur physical activity practicers (and not only them) as these individuals translate or re-signify them as "dietary" or "nutritional" products.

Although the Facebook groups studied never alluded to bodybuilding and the use of supplements in sports, they occasionally mentioned the idea of doping. That is, the creation of discussion topics as to whether or not a product was illegal or sold in the country was also part of the activities of those who exchanged messages there. Sometimes they discussed the need to buy from sellers who brought products from abroad, as some dietary supplements were banned in Brazil by the competent authorities.

Thus, the performance or physical fitness gained by the use of the dietary supplements mentioned by the respondents demonstrates the notions of body-sport or body-performance, which refer to the performance/yield principles of spectacle sport. Vigarello ${ }^{38}$ elaborates on this context by highlighting that sports practices manage to suggest a new representation of the body: the place given to the "energy" principle.

It was also interesting to note that the use of dietary supplements by the practicers was not ex- clusively linked to physical activity. These products were also consumed because of their daily diets:

The be-all-end-all of nutrition is whey protein - the body absorbs it 100\% -, and we strongly need it in order to gain lean mass. Plus, the ingestion of other protein sources also include [undesired] fats. Because of that, I support the notion that the supplement - from its development by NASA to feed astronauts up to today, when it can be found on stores' shelves - facilitates athletes' lives by providing greater assertiveness in the search for healthy nutrition and practices. (Female, 28 years old, engineer).

It helped my diet a lot, especially due to its practicality. (Male, 24 years old, Physical Education teacher).

The thermogenic gives me energy on a daily basis (something I did not use to have), and the protein balances out my hunger. (Female, 29 years old, journalist).

In contemporary times, in which daily time is valued because of all the social demands dietary supplements become a viable alternative for improving nutrition and managing the body. If the practice of physical activities is sometimes considered, in Bourdieu's ${ }^{39}$ perspective, a "luxury," since few can reserve part of their time for such practices, dietary supplements serve as a resource for the rhythm of athletic or ordinary life.

Thus, by ingesting dietary supplements, physical activity practicers would not only be enhancing their physical bodies, but also managing the social roles and relations they deal with daily. Fischler ${ }^{40}$ argues that there is a "nutritional modernity" where the relationship between individuals and their dietary habits has changed substantially in light of the demands that overpower them, especially in large urban centers. In Le Breton's ${ }^{5}$ view, the growing concern with health leads " [...] the actors to be more aware of their bodies, their diets, their daily rhythms. This also unleashes a use of oneself that seeks to restore a balance that is broken, or delicate to maintain, between Modernity's rhythms and those of individuals."5(p.261).

It should be noted that the profile/cover photos of some of the Facebook groups about dietary supplements alluded to nutrition. Although the group administrators displayed images of fruits and vegetables, the predominant contents among the groups were in fact debates over the uses of dietary supplements. This shows how dietary supplements are situated in a fine line between being a natural and an artificial product. 
A large portion of the respondents claimed to be satisfied with their uses of dietary supplements when they related them to physical activities. Many practicers mentioned the idea of results in order to express how they feel when combining supplement use with exercise:

I've achieved satisfactory results; they helped me to reach the results. (Male, 24 years old, physician).

There was a substantial change. (Female, 28 years old, engineer).

Comparing my performance before and after using them, there was a great improvement. (Female, 23 years old, unemployed).

Most of them felt satisfied with their bodies or even their lives after they began using dietary supplements. They stated that there were perceivable differences in their bodies after ingesting these substances regularly, suggesting that they were unwilling to stop buying dietary supplements. Being a participant of the weight training sector almost necessarily means taking such products, because their (bodily) identities are linked to the "eat-exercise" binomial.

Regardless of the possible physiological side effects of dietary supplements, these representations of physical activity practicers demonstrate the symbolic value of these substances for the maintenance of exercise habits. There is a rupture in the experience of these subjects between a "before" and an "after" exercise represented by the ingestion of a substance. For the practicers, body benefits were only achievable by using dietary supplements. Based on Gennep's ${ }^{41}$ classic work, it could be said that these products mark a "rite of passage" between defining one body and another.

The worship and admiration of such substances by physical activity practicers can generate a sense of dependency as their social profits outweigh any health risks. Sometimes relying on physical practices due to the need to manage their own bodies, they may become dependent on dietary supplements ${ }^{23,24}$.

Following Lévi-Strauss' $\mathrm{s}^{42}$ perspective, it can be considered that dietary supplements for physical activity practicers contain a "symbolic efficacy". That is, practicers believe that these substances have an effect on their bodies precisely because they share, believe and suggest it, regardless of resulting physiological impacts. It can be said, therefore, employing one of Mauss's ${ }^{1}$ notions, that dietary supplements have a kind of "mana" - they represent a symbolic force that mobilizes them to produce certain collective beliefs around these products, making them "holy".
However, some respondents relativized or were indifferent to the real impact of dietary supplements on the body. This means that some users of these products understand that ingesting given substances not always directly impacts the body as they expect, or that there is a need to combine their use with other practices, or that it does not generate significant effects:

At the rate I use them and without the combination of a continuous nutrition education, I think they have little effect. (Female, 27 years old, general manager).

It is hard to say exactly what gain resulted exclusively from using the supplement, given that this perception is also related to physical training quality and eating habits. (Male, 31 years old, lawyer).

The truth is that I absolutely don't know the benefits that supplements bring me, as well as to which extent their use is necessary, based on my daily diet. But I let marketing guide me. At least there is a psychological factor that might create results because we believe in their efficiency! (Male, 31 years, executive).

This demonstrates that practicers use nutritional supplements critically and self-reflexively, constantly pondering the real impact of such products on the body. This reality seems to be more complex in the weight training sector, as practicers doubt whether body modifications are linked solely to physical activities or enhanced by products. Frequently, Facebook groups created discussion threads to analyze whether certain products really worked or to share their experiences with certain substances. Thus, the management of the body via the combination of dietary supplements and physical activity is established in an initial period during which the practicer must continually review his self-care practices.

\section{(Dis)continuity of the act of ingesting dietary supplements}

The practicers' body management methods by using dietary supplements were relatively fleeting and discontinuous. Becoming a user of these substances is not a constant process in their opinion:

Since I intend to become pregnant sometime in the future, I believe gestation will be a decisive factor for me to stop. (Female, 31 years old, teacher).

[I use them] for a while (6 or 7 months), then I stop taking them for some time to avoid overloading my organs, and after that I continue. (Male, 37 years old, product development technician).

Nowadays, after I finish my supplement, what I have left, I'll not buy it again. [I decided on this] 
after I learned that you can get results from eating food alone, more so because I'll start having more free time to prepare my meals. (Male, 28 years old, undergraduate).

While some argued that atypical or punctual situations in daily life led them to discontinue their use of dietary supplements, others feared what may occur inside the body with the continued ingestion of these substances. Both objective data - which are often independent of subjects - such as financial investment, pregnancy, chronic and acute pains etc., as well as symbolic data regarding their body representations modulate the ways of using dietary supplements. In other words, using the thought systems described by Levi-Strauss ${ }^{43}$ as a lens, the internal logic of these social groups of practicers does not only move between a rational and a deterministic classification of what can and cannot be used - it also classifies the motivations that drive them to ingest dietary supplements at given times.

Conversely, most respondents reported that they intended to continue taking dietary supplements. Their idea of body maintenance by using these products was intended to provide them positive expectations for the future. This could be noticed when they reported their intentions to keep ingesting dietary supplements in consideration of their numerous benefits to the body and body practices:

Because it makes me feel better and more ready to exercise, in addition to bringing benefits to $m y$ muscle recovery, and also because it helps me keep my vitamins and minerals at a good level. (Male, 32 years old, federal police officer).

Because it gives me stamina for my workouts and that's the only way I can gain muscle mass. (Female, 30 years old, teacher).

In the conceptions of those surveyed, the use of dietary supplements seemed to be the main source of increased body performance in physical activity practices and of body shape definition. They also attributed the maintenance of health and quality of life to such products, or were far from committing themselves to risks that could affect them at present or in the future. Furthermore, the practicers considered that taking dietary supplements prevented them from losing muscle mass.

This reality can be understood in light of the notion of physical or body capital delineated by a few authors ${ }^{44,45}$. When physical activity practicers achieve certain (exercised and supplemented) "bodies", they fear losing their status among the social groups they participate in ${ }^{33,46}$. Should they cease to take the dietary supplements, they run the risk of suffering a sort of symbolic or social death for their inability to manage certain body types.

Others understood that they would keep using dietary supplements to continue a so-called adequate diet with practicality:

Every time I have to do the amount of activities I must do today and do not get the necessary protein reposition. (Male, 33 years old, teacher).

Because they attended to my goal and are already incorporated to my dietary habits. Generally speaking, I have obtained only benefits. (Female, 34 years old, government clerk).

Absolutely!!! Without a doubt. [It's of] total importance! Because it's a continuous cycle; there's no pause in this regard. You follow a daily routine involving training and nutrition, and supplementation's part of the diet too. Everything works together! (Female, 29 years old, unemployed).

There are suggestions that dietary supplements for practicers become an indispensable resource, as a daily diet alone would not be sufficient to maintain the pace of life of those who train body practices. Based on Fischler ${ }^{40}$, understanding that contemporary commensalities regulate what and how much to eat, it can be stated that physical activity practicers share and classify certain ways of managing the body, one of which being what to eat.

Thus, above pondering whether maintaining the use of dietary supplements for body management to achieve a proper and practical diet is moral or immoral, it should be emphasized that the act of eating is inserted or built along a historical-cultural process ${ }^{47,48}$. Lévi-Strauss's ${ }^{49}$ classic work "The Raw and the Cooked" already demonstrated how some types of food and the ways to eat them serve to reflect on certain social relationships.

Lastly, other physical activity practicers maintained their intake of dietary supplements especially because of the supervision of a health professional (often a dietitian), as well as his/her prescription or dietary guidance:

Because my dietitian asked me to keep using them. (Female, 30 years old, dentist).

As long as it's still safe to use them consciously; should I need to interrupt this due to any reason, especially a health-related one, I'll probably follow a professional's orders. (Male, 24 years old, physician).

[I'll] always seek the orientation of someone who's specialized in the subject before taking any sort of product suggested by a supplement store 
clerk. (Male, 36 years old, support analyst).

In these cases, it is shown that practicers who intend to continue the use of dietary supplements are governed by the logics of the health professional who dictates what should be ingested. The practicer's body, therefore, is at the mercy of the universalistic, prescriptive and technical-scientific biomedical rationality that institutes or classifies not only how to perform physical activities, but also which dietary supplements to consume in light of what would be normal or pathological with regard to health prevention or promotion. In a pertinent observation, Le Breton ${ }^{50}$ points out that prevention campaigns linked to public health are concerned precisely with convincing individuals that they are unaware of the "real" risks they incur when pursuing a given behavior.

Thus, the management of the body using dietary supplements, for these subjects, assumes a relation of almost passivity or dependence on the professional embodied by the scientific aegis of biomedical authority. In the context of the use of supplements by physical activity practicers, the object-body delimited by biomedicine is still a reality that fragments it ${ }^{4}$.

Some Facebook groups had profile/cover images of their own products. In most of these groups, they had the purpose of advertising the buying and selling of dietary supplements. Compared to the other groups, it is noteworthy that these spaces were busier in terms of frequency of communication among participants, as each daily discussion revolved around the negotiation of a few products. During the posting of the questionnaire, there were cases in which Facebook group administrators needed to authorize entry. Prior to authorization, a question was asked about the nature of the research to certify whether it was an academic initiative or a commercial action linked to a company.

In this sense, among other arguments, the intention to buy and sell was fundamentally linked to claims that the substances could improve the "health and quality of life" of users. In Le Breton's $\mathrm{s}^{34}$ words, "The human body becomes a continent to be explored, which researchers explore and with which they intend to gain profits" $^{\prime \prime 3}$ (p.121).

Considering that medicalization is defined as a process in which a non-medical problem will be defined and treated as a problem using medical language and format, as well dealt with in terms of disease or disorders ${ }^{51}$, it should also be recalled that uses of dietary supplements may impact the moral control of practicers' bodies. Nowadays, this example is associated with the context of nutritional rationality which food preferences are related to scientific knowledge about eating in a "healthy" way ${ }^{52}$. Therefore, a process of medicalization of dietary supplements is created, which is responsible for creating identities or subjectivities with regard to how to conduct body management when maintaining the practice of physical activities, in addition to a market expansion of products $^{53}$. This phenomenon of contemporaneity can be called healthism or bodyism ${ }^{54,55}$.

\section{Conclusions}

The results suggest that the use of dietary supplements seems to be one of the measures used by physical activity practicers to manage their bodies. More than the practice of physical activities, the ingestion of capsules, gels, tablets and liquids corresponds to the expectation of potentiating the body "always for the better." By moving from the exterior to within the body, these products are sometimes considered determinants of an upgrade of oneself, because physical activities would be limited as to what they could provide the subjects.

Undertaking research on these subjects allows an understanding of how physical activity practicers can manage their own bodies by manipulating substances based on what they share with their groups and social contexts, and how health risks are perceived by them. It also reveals, in part, the logics underlying the act of ingesting these products, which may be fundamental or elucidative for the intervention of Physical Education and Sport professionals, as well as others working in related fields, such as Health, when interacting with their clients or patients.

There are several investigations into dietary supplements based on statistical-biomedical approaches that assume a prescriptive and universalistic rationality, making value judgments about what would be more legitimate for physical activity practicers' improvement. Qualitative studies such as this one, which goes deeper and understands the symbolic particularities of the use of dietary supplements by these individuals, illuminates or provides a resource for quantitative research concerned with the physiological effects or the types of products that are most used by the subjects. Clarifying certain aspects of this reality is important not only for physical and health professionals, or those related, but for all who engage in physical practices. 


\section{Collaborations}

AC Silva was responsible for the field work and development of all stages of the research. SMA Lüdorf was responsible for critically reviewing the content, providing guidance at all stages of the study, as well as for approving the final version of this manuscript.

\section{References}

1. Mauss M. Sociologie et Anthropologie. Paris: PUF; 1993.

2. Rose N. The politics of life itself: biomedicine, power, and subjectivity in the twenty-first century. Oxford: Princeton University Press; 2007.

3. Crossley N. In the gym: motives, meaning and moral careers. Body Soc 2006; 12(3):23-50.

4. Le Breton D. La sociologie du corps. Paris: PUF; 2016.

5. Le Breton D. Anthropologie du corps et modernité. Paris: PUF; 2008.

6. Cornelissen VA, Defoor J, Stevens A, Schepers D, Hespel P, Decramer M, Mortelmans L, Dobbels F, Vanhaecke J, Fagard RH, Vanhees L. Effect of creatine supplementation as a potential adjuvant therapy to exercise training in cardiac patients: a randomized controlled trial. Clin Rehabil 2010; 24(11):988-999.

7. Dunn-Lewis C, Kraemer WJ, Kupchak BR, Kelly NA, Creighton BA, Luk HY, Ballard KD, Comstock BA, Szivak TK, Hooper DR, Denegar CR, Volek JS. A multi-nutrient supplement reduced markers of inflammation and improved physical performance in active individuals of middle to older age: a randomized, double-blind, placebo-controlled study. Nutr J 2011; 10(1):90

8. Outlaw JJ, Wilborn CD, Smith-Ryan AE, Hayward SE, Urbina SL, Taylor L, Foster CA. Effects of a pre -and post-workout protein-carbohydrate supplement in trained crossfit individuals. Springer Plus 2014; $3(1): 1-7$.

9. Oliver AJ, León MT, Hernández EG. Statistical analysis of the consumption of nutritional and dietary supplements in gyms. Arch Lat-Am Nutr 2008; 58(3):221-227.

10. Oliver AJ, León MT, Hernández EG. Prevalence of protein supplement use at gyms. Nutr Hosp 2011; 26(5):1168-1174.

11. RF, Crovetto MM, González AA, Morant CN, Santibáñez TF. Nutritional supplement intake in gymnasium, consumer profile and charateristics of their use. Rev Chil Nutr 2011; 38(2):157-166.

12. Saeedi P, Mohd Nasir MT, Hazizi AS. Differences in sociodemographic, health-related, and psychological factors in users and nonusers of nutritional supplements in fitness club participants in Tehran, Iran. Int $J$ Sport Nutr Exerc Metab 2012; 22(5):323-330.

13. El Khoury D, Antoine-Jonville S. Intake of nutritional supplements among people exercising in gyms in Beirut city. J Nutr Metab 2012; 703490.

14. Saeedi P, Mohd Nasir MT, Hazizi AS, Vafa MR, Foroushani AR. Nutritional supplement use among fitness club participants in Tehran, Iran. Appetite 2013; 60(1):20-26.

15. Tsochas K, Lazuras L, Barkoukis. Psychosocial predictors of nutritional supplement use among leisure time exercisers. Perform Enhanc Health 2013; 2(1):17-23.

16. Nazni P, Vimala S. Nutrition knowledge, attitude and practice of college sportsmen. Asian J Sports Med 2010; 1(2):93-100.

17. Tsitsimpikou C, Chrisostomou N, Papalexis P, Tsarouhas K, Tsatsakis A, Jamurtas A. The use of nutritional supplements among recreational athletes in Athens, Greece. Int J Sport Nutr Exerc Metab 2011; 21(5):377384. 
18. Bianco A, Mammina C, Paoli A, Bellafore M, Battaglia G, Caramazza G, Palma A, Jemni M. Protein supplementation in strength and conditioning adepts: knowledge, dietary behavior and practice in Palermo, Italy. J Int Soc Sports Nutr 2011; 8(25):1-6.

19. Bianco A, Mammina C, Thomas E, Ciulla F, Pupella U, Gagliardo F, Bellafiore M, Battaglia G, Paoli A, Palma A. Protein supplements consumption: a comparative study between the city centre and the suburbs of Palermo, Italy. BMC Sports Sci Med Rehabil 2014; 6:29.

20. Bianco A, Thomas E, Bellafiore M, Martines F, Messina G, Battaglia G. Mediterranean diet and dietary protein supplementation as possible predicting variables of weight management: an update of the protein project. Acta Med. Mediterr 2015; 31(6):1265-1270.

21. Tawfik S, El Koofy N, Moawad EM. Patterns of nutrition and dietary supplements use in young egyptian athletes: a community-based cross-sectional survey. PLoS One 2016; 11(8):1-12.

22. Titan SM, Callas SH, Uip DE, Kalil-Filho R, Galvão PCA. Acute renal failure and hypercalcemia in an athletic young man. Clin. Nephrol 2009; 71(4):445447.

23. Mosley PE. Bigorexia: bodybuilding and muscle dysmorphia. Eur Eat Disord Rev 2009; 17(3):191-198.

24. Rossi L, Tirapegui, J. Exercise dependence and its relationship with supplementation at gyms in Brazil. Nutricion Hospitalaria 2016; 33(2):431-436.

25. Atkinson M. Playing with fire: masculinity, health, and sports supplements. Sociol Sport J 2007; 24(2):165-186.

26. Sabino C, Luz M, Carvalho MC. The end of food: dietary supplementation and diet among avid members of workout and fitness centers in Rio de Janeiro. Hist Cien Saude Manguinhos 2010; 17(2):343-356.

27. Silverman D. Interpreting qualitative data: methods for analyzing, talk, text and interaction. London: Sage; 2006.

28. Dickson-Swift V, James EL, Kippen S, Liamputtong P. Risk to researchers in qualitative research on sensitive topics: issues and strategies. Qual Health Res 2008; 18(1):133-144

29. Wilkerson JM, Iantaffi A, Grey JA, Bockting WO, Rosser BRS. Recommendations for internet-based qualitative health research with hard-to-reach populations. Qual Health Res 2014; 24(4):561-574.

30. Lunnay B, Borlagdan J, McNaughton D, Ward P. Ethical use of social media to facilitate qualitative research. Qual Health Res 2015; 25(1):99-109.

31. Ryan T, Chester A, Reece J, Xenos S. The uses and abuses of Facebook: a review of Facebook addiction. $J$ Behav Addict 2014; 3(3):133-148.

32. Bauer M. Classical Content Analysis. In: Bauer M, Gaskell G, editors. Qualitative researching with text, image and sound: a practical handbook. London: Sage; 2010. p. 131-151.

33. Hutson D. "Your body is your business card": bodily capital and health authority in the fitness industry. $S o c$ Sci Med 2013; 90:63-71.

34. Le Breton D. L'adieu au corps. Paris: Métailié; 1999.

35. Helman C. Dr. Frankenstein and the industrial body: reflections on "spare part" surgery. Anthropology Today 1988; 4(3):14-16.
36. Foucault M. Naissance de la clinique: une archéologie du regard médical. Paris: PUF; 1972.

37. Neville R, Gorman C, Flanagan S, Dimanche F. Negotiating fitness, from consumption to virtuous production. Sociol Sport J 2015; 32(3):284-311.

38. Vigarello G. Passion sport: histoire d'une culture. Paris: Éditions Textuel; 2000.

39. Bourdieu P. La distinction: critique sociale du jugement. Paris: Editions de Minuit; 1979.

40. Fischler C. Gastro-nomía y gastro-anomía: sabiduría del cuerpo y crisis biocultural de la alimentación contemporánea. In: Contreras J, organizador. Alimentación y cultura: necesidades, gustos y costumbres. Barcelona: Universitat de Barcelona Publicaciones; 1995 p. 357-380.

41. Gennep AV. Rites de Passage. Chicago: University of Chicago Press; 1960.

42. Lévi-Strauss C. Structural Anthropology. London: Basic Books; 1963.

43. Lévi-Strauss C. La pensée sauvage. Paris: Plon; 1962.

44. Shilling C. The body and social theory. London: Sage; 2005.

45. Wacquant L. Body and soul: ethnographic notebooks of an apprentice boxer. New York: Oxford University Press; 2004.

46. Frew M, Mcgillivray D. Health clubs and body politics: aesthetics and the quest for physical capital. Leisure 2005; 24(2):161-175.

47. Mintz SW, Bois CM. The antropology of food and eating. Annual Rev Antropol 2002; 31:99-119.

48. Poulain JP. The sociology of food: eating and the place of food in society. London: Bloomsbury Press; 2017.

49. Lévi-Strauss C. The raw and the cooked. Chicago: University of Chicago Press; 1964.

50. Le Breton D. Conduites à risque: des jeux de mort au jeu de vivre. Paris: PUF; 2007.

51. Conrad P. The medicalization of society: on the transformation of human condition into treatable disorders. Baltimore: Johns Hopkins Press; 2007.

52. Viana MR, Neves AS, Camargo Junior KR, Prado SD, Mendonça ALO. A racionalidade nutricional e sua influência na medicalização da comida no Brasil. Cien Saude Colet 2017; 22(2):447-456.

53. Kulkarni M. Protein supplements: an emerging market in the field of nutraceuticals. Pharm Times 2015; 47(9):13-16.

54. Crawford R. Healthism and the medicalization of everyday life. Int J Health Serv 1980; 10:365-388.

55. Cheek J. Healthism: a new conservatism? Qual Health Res 2008; 18(7):974-982.

Article submitted 16/03/2020

Approved 15/08/2020

Final version submitted $17 / 08 / 2020$

Chief editors: Romeu Gomes, Antônio Augusto Moura da Silva 
